Bul. Agrohorti 7(3): 263-269 (2019)

\title{
Studi Perkecambahan Benih Ciplukan (Physalis peruviana L.) Pada Beberapa Tingkat Masak Buah
}

\author{
The Studies of Cape Gooseberry (Physalis peruviana L.) Seed Germination at Different Fruit Maturity
}

Norul Dewi Susanti, Eny Widajati*, dan Dwi Guntoro

Departemen Agronomi dan Hortikultura, Fakultas Pertanian, Institut Pertanian Bogor

(Bogor Agricultural University), Jl. Meranti, Kampus IPB Dramaga, Bogor 16680, Indonesia

Telp. \& Faks. 0251-8629353 email agrohort@apps.ipb.ac.id

*Penulis Korespondensi: eny_widajati@apps.ipb.ac.id

Disetujui : 6 Maret 2020 / Publish Online Mei 2020

\begin{abstract}
Cape gooseberry is a plant with many benefits. Increasing demand of cape gooseberry fruit, opens opportunities for farmers. The problem that faced by farmers is the unavailability of quality seeds. Information about cape gooseberry seed germination is still very little, so it is necessary to develop a study on cape gooseberry seed germination. The objective of this research was to determine the method of germination testing and determine the effect of maturity levels and seed treatment before germination on cape gooseberry seed germination. Research was conducted at Laboratory of Seed Science and Technology IPB from February to April 2019. The experiment was arranged in a completely randomize block design $(C R B D)$ using two factor. The first factor is the level of seed ripening which is indicated by the color of fruit the petals, that was yellowish green, yellow and brown. The second factor is the treatment before germination, that was without treatment, soaking the seeds with distilled water and soaking with $\mathrm{KNO}_{3} 0.2 \%$ for 24 hour. The results showed that the first count and final count of germination was 14 HSP and 28 HSP. Based on observations of vigor index and speed of germination, the best seed harvest could be done when the fruit petals was yellow to brown. Seed treatment before germination with $\mathrm{KNO}_{3}$ markedly increased the germination at the level of yellow maturity.
\end{abstract}

Keywords: germination, opportunity, speed of germination, vigor index

\begin{abstract}
ABSTRAK
Ciplukan merupakan tanaman dengan banyak manfaat. Permintaan buah ciplukan yang meningkat menjadi peluang yang baik bagi petani. Masalah yang dihadapi petani adalah belum tersedianya benih bermutu. Informasi mengenai perkecambahan benih ciplukan masih sangat sedikit, sehingga perlu dilakukan pengembangan terhadap studi perkecambahan benih ciplukan. Penelitian ini bertujuan untuk menentukan metode pengujian daya berkecambah dan mengetahui pengaruh tingkat masak dan perlakuan benih sebelum pengecambahan pada perkecambahan benih ciplukan. Penelitian dilaksanakan di Laboratorium Ilmu dan Teknologi Benih IPB pada bulan Februari sampai dengan April 2019. Penelitian menggunakan rancangan kelompok lengkap teracak (RKLT) dua faktor. Faktor pertama yaitu tingkat masak benih yang diindikasikan oleh warna kelopak buah yaitu hijau kekuningan, kuning dan coklat. Faktor kedua adalah perlakuan sebelum pengecambahan yaitu tanpa perlakuan, perendaman benih dengan aquades dan perendaman dengan $\mathrm{KNO}_{3}$ $0.2 \%$ selama 24 jam. Hasil penelitian menunjukan bahwa pengamatan daya berkecambah hitungan pertama adalah pada 14 HSP dan hitungan kedua pada 28 HSP. Berdasarkan pengamatan indeks vigor dan kecepatan tumbuh, panen benih terbaik dapat dilakukan ketika kelopak buah berwarna kuning hingga coklat. Perlakuan benih sebelum pengecambahan dengan $\mathrm{KNO}_{3}$ nyata meningkatkan daya berkecambah pada tingkat masak kuning.
\end{abstract}

Kata kunci: daya berkecambah, indeks vigor, kecepatan tumbuh, peluang 


\section{PENDAHULUAN}

Masyarakat diberbagai belahan dunia telah mengalami peningkatan pengetahuan mengenai gaya hidup sehat. Seiring berkembangnya pengetahuan, muncul berbagai jenis tanaman yang digolongkan sebagai superfood seperti kelor, ketan hitam, ubi ungu, dan manggis. Bloomberg (2018) menyatakan bahwa ciplukan juga termasuk dalam superfood berdasarkan kandungan nutrisi dan manfaat yang ditemukan pada tanaman ini.

Ciplukan atau Physalis peruviana L. merupakan tanaman berbentuk semak yang termasuk anggota famili Solanaceae. Tanaman ini berasal dari Peru, Amerika Latin yang sudah menyebar luas ke daerah subtropis dan tropis terutama Asia dan Afrika (Azwar, 2010). Ciplukan telah banyak dibudidayakan dan dikomersialkan untuk konsumsi sebagai buah. Selain itu, bagian tanaman ciplukan seperti batang, daun dan akarnya juga banyak digunakan sebagai obat dan campuran pada komposisi kosmetik. Pada tanaman ciplukan terdapat berbagai macam kandungan kimia berupa glikosida, flavonoid, alkaloid, steroid, fisalin, tanin, kriptoxantin, vitamin $\mathrm{C}$, protein, minyak lemak, asam linoleat, asam oleat, asam falmitat, dan asam asetat yang bermanfaat dalam bidang obat-obatan (Licodiedoff et al., 2013). Oliveira et al. (2016) juga mengatakan bahwa ciplukan bermanfaat untuk pemurnian darah, pengurangan albumin pada ginjal, rekontruksi dan penguatan saraf otak, serta pengobatan penyakit prostat.

Perusahaan pionir agribisnis ciplukan (Physalis peruviana L.) pertama di Indonesia adalah Waida Farm. Saat ini target pasar Waida Farm hanya mencakup Pulau Jawa dengan jumlah pengiriman lebih kurang $200 \mathrm{~kg}$ /bulannya (Nugraha dan Ernah, 2018). Tingginya permintaan dan belum banyaknya pelaku usaha menjadi peluang bagi petani untuk membudidayakan tanaman ini. Perbenihan menjadi rantai awal dan penting dalam mencapai keberhasilan pengembangan tanaman ciplukan di Indonesia.

Pertumbuhan bibit di lapangan akan baik jika kecambah tumbuh dengan baik pada fase perkecambahan. Menurut Kamil (1986) untuk keperluan pengujian benih persyaratan yang harus dipenuhi diantaranya air, suhu, oksigen, dan cahaya, begitu juga dengan media perkecambahan yang menentukan keberhasilan pengujian benih tersebut. Nunes et al. (2018) menyatakan bahwa benih ciplukan (Physalis peruviana L.) akan berkecambah dengan baik pada suhu $27{ }^{\circ} \mathrm{C}$ atau
$30{ }^{\circ} \mathrm{C}$, dengan fotoperiodisasi lebih dari 8 jam, dengan umur simpan benih selama 12 bulan.

Informasi perkecambahan benih ciplukan masih sangat terbatas. Ozaslan et al. (2017) menyatakan bahwa ciplukan (Physalis angulata L.) memiliki sifat dormansi sehingga diperlukan perlakuan pra-tanam untuk meningkatkan perkecambahan. Menurut ISTA (2014) pada Physalis pubescens hitungan pertama dan kedua dilakukan pada 7 dan 28 hari setelah pengecambahan (HSP), dengan metode pematahan dormansi yaitu menggunakan $\mathrm{KNO}_{3}$. Informasi mengenai perkecambahan Physalis peruviana L. juga masih terbatas. Berdasarkan hal tersebut, penelitian tentang studi perkecambahan benih ciplukan (Physalis peruviana L.) penting dilakukan. Penelitian ini bertujuan menentukan metode pengujian daya berkecambah benih ciplukan dan mengetahui pengaruh tingkat masak buah dan perlakuan benih sebelum pengecambahan pada perkecambahan benih ciplukan (Physalis peruviana L.).

\section{BAHAN DAN METODE}

Penelitian ini dilakukan di Laboratorium Ilmu dan Teknologi Benih, Departemen Agronomi dan Hortikultura, Fakultas Pertanian, Institut Pertanian Bogor. Penelitian ini dilaksanakan pada bulan Februari sampai dengan April 2019. Bahan yang digunakan dalam penelitian ini adalah buah ciplukan (Physalis peruviana L.) yang baru dipanen. Panen dilakukan pada tanggal 14 Februari 2019. Benih diambil dari kebun Waida Farm Kelurahan Pamulihan Kabupaten Sumedang dengan ketinggian tempat 800 mdpl. Untuk mendapatkan lot benih yang berbeda maka buah dikelompokan atas tiga tingkat masak yang diindikasikan dengan warna kelopak buah, yaitu hijau kekuningan, kuning dan coklat (Lampiran 1). Bahan lain yang digunakan pada penelitian adalah aquades, kertas label, kotak pengecambah, larutan $\mathrm{KNO}_{3} 0.2 \%$, dan plastik. Media pengecambahan berupa kertas buram (CD) dan tisu.

Rancangan percobaan yang digunakan yaitu rancangan kelompok lengkap teracak (RKLT) dua faktor. Faktor pertama adalah tingkat masak benih yang diindikasikan dengan warna kelopak buah, yaitu hijau kekuningan, kuning, dan coklat. Faktor kedua adalah perlakuan sebelum pengecambahan, yaitu : tanpa perlakuan, perendaman dengan aquades 24 jam dan perendaman dengan $\mathrm{KNO}_{3}$ $0.2 \%$ selama 24 jam. Percobaan diulang sebanyak 
tiga kali, sehingga terdapat 27 satuan percobaan yang masing-masing menggunakan 100 butir benih/tolok ukur/ulangan.

Jumlah buah yang diekstraksi pada setiap tingkat masak yaitu 50 buah dengan kelopak hijau kekuningan, 45 buah dengan kelopak kuning, dan 40 buah dengan kelopak coklat. Ekstraksi benih ciplukan dilakukan berdasarkan Chaidir et al. (2015) dengan cara merendam benih dalam air. Perendaman dilakukan selama 24 jam. Setelah itu benih dicuci bersih kemudian disaring dan dilakukan seleksi. Benih diseleksi dengan memilih benih yang bernas, bentuknya seragam, permukaan kulit bersih, serta membuang benih yang afkir. Ciri-ciri benih afkir yaitu benih yang mengapung ketika direndam dan benih yang tenggelam namun terdapat cacat fisik. Setelah itu, benih ditiriskan dan dijemur 4 jam selama dua hari sampai benih mencapai kadar air 7-10\%. Setelah pengeringan, benih ciplukan dikemas menggunakan klip plastik dan di beri label, kemudian disimpan dalam ruang penyimpanan dengan suhu $18^{\circ} \mathrm{C}$.

Pengecambahan benih untuk semua uji dilakukan dengan metode uji di atas kertas (UDK) dengan tiga ulangan. Sebelum dikecambahkan, benih terlebih dahulu diberi perlakuan, yaitu tanpa perlakuan, perendaman dengan aquades selama 24 jam, dan perendaman dengan $\mathrm{KNO}_{3}$ selama 24 jam. Pengecambahan dilakukan pada kotak pengecambah berdimensi 17 $\mathrm{cm}$ x $5 \mathrm{~cm}$. Media tanam yang digunakan yaitu tiga lembar kertas buram dan selembar tisu yang telah dilembabkan dengan akuades. Uji tersebut dilakukan dengan mengecambahkan benih sebanyak 100 butir untuk setiap ulangan. Benih dikecambahkan pada pada suhu ruang, yaitu pada suhu $27-30{ }^{\circ} \mathrm{C}$.

Pengamatan uji daya berkecambah (DB) pada 14 dan 28 hari setelah pengecambahan (HSP), indeks vigor (IV) pada 14 HSP, kecepatan tumbuh $\left(\mathrm{K}_{\mathrm{CT}}\right)$, bobot kering kecambah normal
(BKKN), radicle emergence (RE) dan laju pertumbuhan kecambah (LPK) secara lengkap.

Data pengamatan diuji analisis ragam dengan menggunakan software SAS dan Ms. Exel 2010. Sidik ragam dilakukan untuk mengetahui pengaruh perlakuan sebelum pengecambahan dan tingkat kemasakan buah. Apabil uji F perlakuan pada taraf $(\alpha) 5 \%$ berpengaruh nyata, maka akan dilakukan uji lanjut menggunakan uji Duncan Multiple Range Test (DMRT). Hasil pengujian RE dikorelasikan dengan hasil uji tolok ukur mutu fisiologis benih.

\section{HASIL DAN PEMBAHASAN}

Ciplukan memiliki rata-rata jumlah benih 220 butir/buah. Hal ini sesuai dengan Muniz (2014) yang menyatakan bahwa dalam buah ciplukan terdapat 100-300 benih. Jumlah benih ditentukan oleh jumlah ovul yang terbuahi saat terjadinya penyerbukan, sehingga jumlahnya tidak berbeda nyata tiap tingkat kemasakan. Pada mentimun (Cucumis sativus L.) pembentukan buah dan benih ditentukan oleh waktu penyerbukan sehingga pada setiap tingkat kemasakan tidak memiliki perbedaan jumlah yang signifikan (Harliani et al., 2014).

Hasil analisis ragam pada Tabel 1 menunjukan bahwa perbedaan tiga tingkat masak berpengaruh sangat nyata terhadap bobot kering benih, namun tidak berbengaruh terhadap kadar air benih. Bobot kering benih pada tingkat masak kuning dan coklat nyata lebih tinggi dibandingkan pada tingkat masak hijau. Salah satu yang menyebabkan perbedaan bobot benih adalah kandungan endosperma pada benih (Darmawan, 2014). Hal ini menunjukan bahwa pada tingkat kemasakan kuning dan coklat memiliki kandungan cadangan makanan pada benih tinggi dan telah mencapai masak fisiologis ditandai bobot kering benih telah maksimum.

Tabel 1. Data bobot 1000 butir, kadar air, dan bobot kering benih ciplukanpada beberapa tingkat kemasakan

\begin{tabular}{ccccc}
\hline Warna Kelopak & $\begin{array}{c}\text { Rata-rata } \\
\text { Sbenih/buah } \\
\text { (butir) }\end{array}$ & $\begin{array}{c}\text { Bobot } 1000 \\
\text { Butir }(\mathrm{g})\end{array}$ & $\begin{array}{c}\text { KA } \\
(\%)\end{array}$ & $\begin{array}{c}\text { BKB } \\
(\mathrm{g})\end{array}$ \\
\hline Hijau kekuningan & 212 & 0.8400 & 10.1532 & $0.7267 \mathrm{~b}$ \\
Kuning & 213 & 0.8871 & 7.9377 & $0.8301 \mathrm{a}$ \\
Coklat & 234 & 0.8508 & 9.0326 & $0.8181 \mathrm{a}$ \\
\hline Uji F & & tn & $* *$ \\
\hline
\end{tabular}

Keterangan: $\quad \operatorname{tn}=$ tidak berpengaruh nyata; $*=$ berpengaruh nyata; $* *=$ berpengaruh sangat nyata pada $\alpha=5 \%, \mathrm{KA}=$ kadar air, $\mathrm{BKB}=$ bobot kering benih. 
Pengamatan hitungan pertama tidak dilakukan pada 7 HST karena pada saat itu kecambah yang mencapai normal masih sangat sedikit. Hitungan kedua ditentukan pada 28 HST karena pada hitungan tersebut diperkirakan pertumbuhan kecambah menjadi normal sudah maksimum.

Pada akhir pengamatan daya berkecambah, semua kecambah dihitung baik normal, abnormal maupun benih mati. Kriteria kecambah normal kuat, normal lemah dan abnormal dapat dilihat pada Tabel 2.

Pengamatan yang diamati terdiri atas parameter DB, IV, $\mathrm{K}_{\mathrm{CT}}$, dan PTM. Pengamatan dilakukan untuk melihat pengaruh tingkat kemasakan dan perlakuan benih. Perendaman benih dengan $\mathrm{KNO}_{3}$ dilakukan karena pada ISTA (2104) telah direkomendasikan bahwa pematahan dormansi pada benih ciplukan dapat dilakukan dengan $\mathrm{KNO}_{3}$.

Analisis ragam pada Tabel 3 menunjukan bahwa baik perlakuan benih sebelum pengecambahan maupun tingkat kemasakan berpengaruh sangat nyata terhadap tolok ukur DB, namun tidak berpengaruh pada tolok ukur IV, $\mathrm{K}_{\mathrm{CT}}$ dan PTM. Interaksi antar perlakuan berpengaruh sangat nyata pada tolok ukur DB dan $\mathrm{K}_{\mathrm{CT}}$, berpengaruh nyata pada IV, dan tidak berpengaruh terhadap tolok ukur PTM.

Tabel 2. Kriteria kecambah normal dan abnormal ciplukan

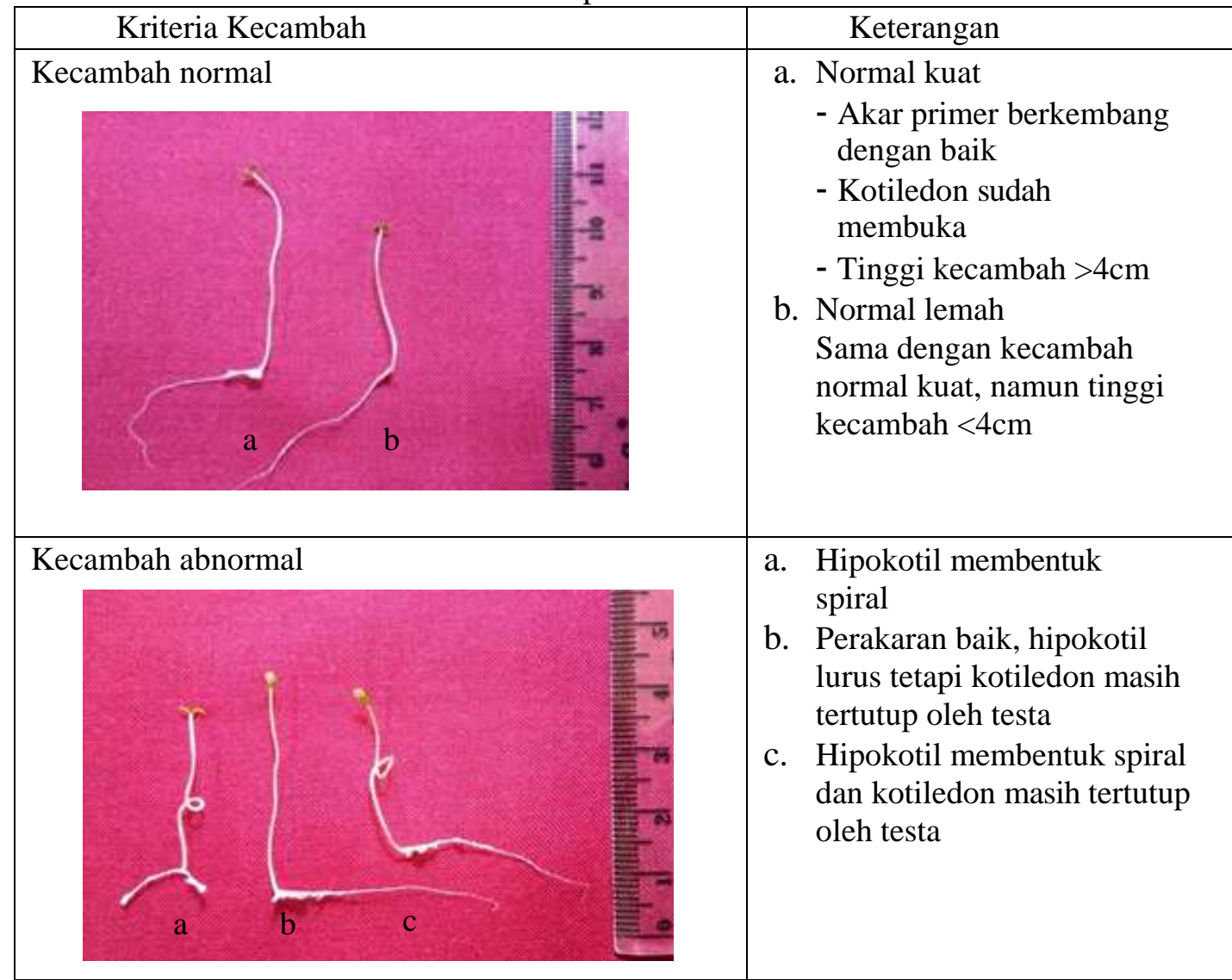

Tabel 3. Hasil analisis ragam perlakuan terhadap mutu fisiologis benih

\begin{tabular}{lcccc}
\hline Perlakuan & DB & IV & KCT & PTM \\
\hline Perlakuan benih & $11.12^{* *}$ & $3.00^{\text {th }}$ & $3.49^{\text {tn }}$ & $3.00^{\text {tn }}$ \\
Warna & $7.21^{* *}$ & $0.87^{\text {tn }}$ & $0.25^{\text {tn }}$ & $3.25^{\text {tn }}$ \\
Interaksi antar perlakuan & $13.28^{* *}$ & $4.74^{*}$ & $7.27^{* *}$ & $0.25^{\text {tn }}$ \\
\hline
\end{tabular}

Keterangan: $\quad \operatorname{tn}=$ tidak berpengaruh nyata; $*$ =berpengaruh nyata; $* *=$ berpengaruh sangat nyata pada $\alpha=5 \%$. $\mathrm{DB}=$ daya berkecambah, $\mathrm{IV}=$ indeks vigor, $\mathrm{K}_{\mathrm{CT}}=$ kecepatan tumbuh, $\mathrm{PTM}=$ potensi tumbuh maksimum 
Bul. Agrohorti 7(3): 263-269 (2019)

Daya berkecambah benih ciplukan menunjukan nilai yang masih rendah (Tabel 4). Namun, potensi tumbuh maksimum pada semua lot benih memiliki nilai yang tinggi yaitu 98100\% (Tabel 5). Hal ini disebabkan karena masih banyaknya kecambah abnormal pada akhir waktu pengamatan. Kecambah abnormal yang banyak ditemukan pada akhir pengamatan adalah kecambah dengan perakaran yang baik, hipokotil lurus tetapi kotiledon masih tertutup testa. Kecambah tersebut berpotensi untuk menjadi kecambah normal, sehingga disarankan waktu pengamatan hitungan kedua diperpanjang. Nilai PTM yang tinggi menunjukan tidak adanya dormansi pada benih ciplukan.
Indeks vigor dan kecepatan tumbuh merupakan parameter dari vigor benih. Vigor benih dapat memberikan informasi mengenai keseragaman pertumbuhan bibit di lapangan (Powell dan Matthews, 2005). Berdasarkan hasil dapat dilihat bahwa nilai IV dan $\mathrm{K}_{\mathrm{CT}}$ memiliki kecenderungan hasil yang hampir sama. Nilai IV dan KCT pada masak hijau masih rendah, namun pada tingkat masak kuning dan coklat memiliki nilai yang lebih tinggi. Berdasarkan hal tersebut, panen benih ciplukan yang tepat dapat dilakukan pada saat kelopak buah berwarna kuning sampai coklat. Perlakuan benih terlihat efektif diaplikasikan pada tingkat masak hijau tetapi tidak pada tingkat masak lain.

Tabel 4. Pengaruh interaksi perlakuan benih dan tingkat masak terhadap daya berkecambah, indeks vigor dan kecepatan tumbuh

\begin{tabular}{|c|c|c|c|}
\hline \multirow{2}{*}{ Perlakuan Benih } & \multicolumn{3}{|c|}{ Tingkat Masak } \\
\hline & Hijau & Kuning & Coklat \\
\hline & \multicolumn{3}{|c|}{ DB (\%). } \\
\hline Tanpa perlakuan & $53.00 \mathrm{bc}$ & $46.00 \mathrm{~d}$ & $47.70 \mathrm{~cd}$ \\
\hline Aquades & $58.60 \mathrm{ab}$ & $48.60 \mathrm{~cd}$ & $60.00 \mathrm{a}$ \\
\hline \multirow[t]{2}{*}{ KNO3 } & $56.30 \mathrm{ab}$ & $59.70 \mathrm{a}$ & $45.00 \mathrm{~d}$ \\
\hline & \multicolumn{3}{|c|}{ IV $(\%)$} \\
\hline Tanpa perlakuan & $16.33 b$ & $37.33 \mathrm{a}$ & $41.33 \mathrm{a}$ \\
\hline Aquades & $36.00 \mathrm{a}$ & $28.67 \mathrm{a}$ & $43.67 \mathrm{a}$ \\
\hline \multirow[t]{2}{*}{ KNO3 } & $36.00 \mathrm{a}$ & $41.00 \mathrm{a}$ & $30.33 a$ \\
\hline & \multicolumn{3}{|c|}{$\mathrm{K}_{\mathrm{CT}}(\%$ etmal-1). } \\
\hline Tanpa perlakuan & $2.725 \mathrm{~d}$ & $4.800 \mathrm{a}$ & $4.456 \mathrm{a}$ \\
\hline Aquades & $2.821 \mathrm{~d}$ & $3.531 \mathrm{bc}$ & $3.696 \mathrm{bc}$ \\
\hline KNO3 & $3.534 b c$ & $3.422 \mathrm{c}$ & $3.943 b$ \\
\hline
\end{tabular}

Keterangan : angka yang diikuti huruf yang sama tidak berbeda nyata berdasarkan uji DMRT $\alpha 0.05$; $\mathrm{DB}=$ daya berkecambah, $\mathrm{IV}=$ indeks vigor, $\mathrm{K}_{\mathrm{CT}}=$ kecepatan tumbuh

Tabel 5. Jumlah kecambah normal, abnormal, dan benih mati pada pengamatan potensi tumbuh maksimum

\begin{tabular}{lcccc}
\hline \multicolumn{1}{c}{ Perlakuan } & Normal & Abnormal & Mati & $\begin{array}{c}\text { Jumlah kecambah } \\
\text { tumbuh }\end{array}$ \\
\hline Hijau, tanpa perlakuan & 53 & 45 & 2 & \\
Hijau, aquades & 51 & 47 & 2 & 98 \\
Hijau, KNO3 & 56 & 43 & 1 & 98 \\
Kuning, tanpa perlakuan & 46 & 53 & 1 & 99 \\
Kuning, aquades & 44 & 56 & 0 & 99 \\
Kuning, KNO3 & 59 & 41 & 0 & 100 \\
Coklat, tanpa perlakuan & 52 & 47 & 1 & 100 \\
Coklat, aquades & 52 & 47 & 1 & 99 \\
Coklat, KNO3 & 45 & 55 & 0 & 99 \\
\hline
\end{tabular}


Bul. Agrohorti 7(3): 263-269 (2019)

Tabel 6. Koefisien korelasi (r) antara RE pada setiap periode pengecambahan dengan tolok ukur mutu fisiologis

\begin{tabular}{ccccc}
\hline Waktu pengamatan & \multicolumn{4}{c}{ Tolok Ukur } \\
\cline { 2 - 5 } & DB & IV & KCT & PTM \\
\hline 192 & $0.040^{\text {tn }}$ & $-0.133^{\text {tn }}$ & $-0.096^{\text {tn }}$ & $-0.073^{\text {tn }}$ \\
197 & $0.044^{\text {tn }}$ & $-0.130^{\text {tn }}$ & $-0.093^{\text {tn }}$ & $-0.075^{\text {tn }}$ \\
202 & $0.055^{\text {tn }}$ & $-0.109^{\text {tn }}$ & $-0.065^{\text {tn }}$ & $-0.091^{\text {tn }}$ \\
207 & $-0.063^{\text {tn }}$ & $-0.110^{\text {tn }}$ & $-0.057^{\text {tn }}$ & $0.007^{\text {tn }}$ \\
212 & $-0.078^{\text {tn }}$ & $-0.133^{\text {tn }}$ & $-0.079^{\text {tn }}$ & $0.007^{\text {tn }}$ \\
217 & $-0.050^{\text {tn }}$ & $-0.117^{\text {tn }}$ & $-0.058^{\text {tn }}$ & $0.000^{\text {tn }}$ \\
222 & $-0.038^{\text {tn }}$ & $-0.115^{\text {tn }}$ & $-0.051^{\text {tn }}$ & $0.004^{\text {tn }}$ \\
227 & $0.030^{\text {tn }}$ & $-0.007^{\text {tn }}$ & $0.068^{\text {tn }}$ & $0.047^{\text {tn }}$ \\
232 & $0.393^{\text {tn }}$ & $0.254^{\text {tn }}$ & $0.377^{\text {tn }}$ & $0.059^{\text {tn }}$ \\
237 & $0.495^{* *}$ & $0.066^{\text {tn }}$ & $0.153^{\text {tn }}$ & $-0.002^{\text {tn }}$ \\
\hline
\end{tabular}

Keterangan : tn: tidak berbeda nyata, $*=$ berbeda nyata, ${ }^{* *}=$ berbeda sangat nyata pada uji DMRT $\alpha=5 \%$; DB=daya berkecambah, IV=indeks vigor, $\mathrm{K}_{\mathrm{CT}}=$ kecepatan tumbuh, $\mathrm{PTM}=$ potensi tumbuh maksimum

Pengujian vigor benih juga dilakukan pada tolok ukur radicle emergence (RE). Interaksi antara tingkat masak dan perlakuan benih memberikan pengaruh yang tidak nyata pada semua periode pengamatan RE (Lampiran 3). Namun pada periode pengamatan 237 JST nilai RE memberikan hasil yang maksimum dan menunjukan kecenderungan yang sama dengan daya berkecambah. Untuk mengetahui hubungan antara periode pengamatan RE dan tolok ukur lain dilakukan analisis korelasi diantara keduanya. Hasil korelasi dapat dilihat pada Tabel 6.

Berdasarkan hasil analisis terdapat korelasi positif dan cukup erat antara RE dan DB yaitu pada periode pengamatan 232 dan 237 JST dengan nilai r 0.393 dan 0.495 . Berdasarkan hasil tersbut dapat direkomendasikan bahwa pengamatan RE dapat dilakukan pada kisaran 232 sampai 237 JST.

\section{KESIMPULAN}

Pengamatan daya berkecambah hitungan pertama adalah pada hari ke-7 HSP dan hitungan kedua pada hari ke-28 HSP. Berdasarkan pengamatan indeks vigor dan kecepatan tumbuh, panen benih terbaik dapat dilakukan ketika kelopak buah berwarna kuning hingga coklat. Perlakuan benih sebelum pengecambahan dengan $\mathrm{KNO}_{3}$ nyata meningkatkan daya berkecambah pada tingkat masak kuning. Penelitian lebih lanjut mengenai perkecambahan benih ciplukan perlu dilakukan untuk menentukan waktu pengamatan perkecambahan yang tepat sehingga persentase kecambah normal dapat maksimum. Pengamatan radicle emergence disarankan pada jam 232-237 JST. Perlu digunakan variasi lot yang lebih banyak sehingga hasil yang diberikan lebih spesifik. 
Bul. Agrohorti 7(3): 263-269 (2019)

\section{DAFTAR PUSTAKA}

Azwar, A. 2010. Tanaman Ciplukan, Tanaman Obat Indonesia. Salemba Medika, Jakarta, ID.

Bloomberg, A. 2018. Multinational wants cape gooseberry to be their new superfood.https://www.freshplaza.com/artic le/2201209/multinational-wants-cape gooseberries-to-be-their-new-superfood/ [24 Agustus 2019].

Chaidir, L., Epi, A. Taofik. 2015. Eksplorasi, identifikasi, dan perbanyakan tanaman ciplukan (Physalis angulata L.) dengan menggunakan metode generatif dan vegetatif. ISSN 1979-8911. 9(1):82-103.

Darmawan, A.C., Respatijarti, Soetopo, L. 2014. Pengaruh tingkat kemasakan benih terhadap pertumbuhan dan produksi cabai rawit (Capsicum frutescent $\mathrm{L}$.) varietas comexio. Jurnal Produksi Tanaman 2(4):339-364.

Harliani, E.N., E.R. Palupi, D.S. Wahyudin. 2014. Potensi penyimpanan serbuk sari dalam produksi benih hibrida mentimun (Cucumis sativus L.) varietas KE041. J. Hort. Indonesia 5(2):104-117.

[ISTA] International Seed Testing Association. 2014. International Rules for Seed Testing. The International Seed Testing Association (ISTA), Bassersdorf, CH-Switzerland.

Licodiedoff, S., L.A.D. Koslowski, R.H. Ribani. 2013. Flavonols and antioxidant activity of Physalis peruviana L. fruit at two maturity stages. Acta Scientiarum Technology 35:393-399.
Kamil, J. 1986. Teknologi Benih Jilid 1. Angkasa Raya, Padang, ID.

Muniz, J., A.A. Kretzschmar, L. Rufato, T.R. Pelizza, A.D.R Rufato, T.A.D Macedo. 2014. General aspects of physalis cultivation. Cienc. Rural 44(6):964-970.

Nugraha, M.K., Ernah. 2018. Strategi pengembangan agribisnis buah ciplukan (Physalis peruviana L.) di Waida Farm Jawa Barat. Agricore 3(2):537-547.

Nunes. A.L., S. Sossmeier, A.P, Gotz, N.B. Bispo.2018. Germination eco-physiology and emergence of Physalis peruviana seedling. Journal of Agricultural Science and Technology 8:352-359.

Olivera, S.F., F.J.A. Goncalves, P.M.R. Correia, R.P.F. Guine. 2016. Physalis properties of Physalis peruviana L. Open Agriculture 1:55-59.

Ozaslan, C., S. Farooq, H. Onen, S. Ozcan, B. Bukun, H. Gunal. 2017. Germination biology of two invasive physalis species and implications for their management in arid and semi-arid regioins. www.nature.com/scientificreports $\quad[1$ Agustus 2019].

Powell, A. A., S. Matthews. 2005. Towards the validation of the controlled deterioration vigour test for small seeded vegetables. Seed Testing Int. ISTA News Bull. 129:2124. 